\title{
The IMF and East Asia: A Changing Regional Financial Architecture
}

\begin{abstract}
The financial crises of 1997 and 1998 have had a profound effect on how East Asia sees the role of the IMF and its strategic interests relative to those of the United States in international finance. The crises have spurred demand for a regional financial architecture in East Asia - ranging from deeper policy dialogue and surveillance, a system of financial cooperation, and even talk of common exchange rate arrangements. This paper analyses the economic, strategic and chauvinistic motivations behind this, and evaluates the merit of some of these proposals. Regional policy dialogue and surveillance in East Asia are weak, and the strengthening that is occurring through the ASEAN+3 grouping is welcome and important. There is also a strong case to be made for regional financial cooperation to complement global arrangements. A regional arrangement can secure liquidity and financing support to respond to small or localised crises, and may be a more effective preventive measure than the IMF's Contingent Credit Line facility. A regional arrangement would also boost policy dialogue and surveillance. But progress to date has been slow.
\end{abstract}

\section{Introduction}

The financial crises of 1997 and 1998 have had a profound effect on East Asia's view of international financial and monetary arrangements, including the role of the International Monetary Fund in international policy dialogue and financial cooperation. ${ }^{1}$ There has been a tectonic shift in the policy landscape of the region. ${ }^{2}$ While there are differences between and within countries, no longer is East Asia content to rely almost exclusively on global forums, mechanisms and institutions; it now wants to develop a complementary regional structure. The process of developing a regional economic and financial architecture may be in its early stages but the political and policy dynamics under way make it irreversible.

There are many elements to the expansion of regional arrangements - ranging from strengthened policy dialogue, greater financial cooperation, deeper economic and trade integration, and even common currency arrangements. Much of the content of the evolving debate and policy on regional financial arrangements is tied directly to the region's discontent with the IMF and its concomitant disillusion with the way the United States dealt with the 
financial crisis in East Asia. It is also motivated by a profound sense that deep economic and financial integration in East Asia can be of substantial benefit, both nationally and internationally, to countries in the region. At the same time, the European experience is seen as compelling.

The IMF is widely seen in East Asia as having performed poorly in the financial crises of 1997 and 1998, although its performance did improve later in the crisis and it is credited with being more responsive to the region's concerns since then. The Fund's sins in East Asia are perceived by its critics to be many: it initially interpreted the crisis incorrectly, it forced countries to adopt macroeconomic and structural policies that did not support confidence and recovery, ${ }^{3}$ it was rigidly ideological in its analysis of hedge funds and initial dismissal of the possibility of destabilising speculation in financial markets, ${ }^{4}$ and it was not able to garner the support of the United States and Europe in dealing with the crisis at critical stages in 1997 and 1998. Rather than being credited as a key independent player, it was seen as US-run and dominated, ideological and inflexible, and obsessed with protecting its own bureaucratic interests. ${ }^{5}$

Despite this experience, there is no appetite in (most of) the region for doing away with the Fund. It plays far too valuable a role: it is a key resource for technical assistance and analysis; it is essential in dealing with broad-based or global financial crises, including securing private-sector involvement; it is a useful tool for politicians to push domestic reform; it provides a voice for smaller countries at the global level; and it is a key device in securing US and European interest in the world outside their borders and immediate regions. But there is a profound sense in much of East Asia that international financial policymaking and cooperation cannot proceed only on the global level; it must be complemented by strong, welldesigned regional financial arrangements. These financial arrangements encompass strengthened policy dialogue, financial cooperation and perhaps common currency arrangements in East Asia.

This paper analyses the regional financial architecture that is emerging in East Asia. It looks at the complex economic, strategic and chauvinistic motivations for establishing new regional arrangements, and at how the interplay between these factors has changed since mid1997, as emotions have been moderated by the practicalities and broader strategic interests of the region. An understanding of these motivations is important in deciding how to respond to the new Asian regionalism: opponents who summarily dismiss it are likely to fuel the fire because they ignore crucial strategic and chauvinistic elements at play. 
The paper then looks in more detail at the evolving policy agenda on regional financial arrangements, critically examining the value of regional policy dialogue and the functioning of policy forums. It looks at what is meant by regional financial cooperation, whether such cooperation should be regional or global, and what the state of play is in East Asia.

\section{Motivation for a new regional financial architecture}

The debate about regional financial arrangements is a complex one, as the motivation for the new regional financial architecture has many dimensions. These can be broadly categorised into economic, strategic and chauvinistic rationales.

\section{Economic reasons}

The economic rationale for new regional financial arrangements has two main aspects.

The first is the perceived need for a mechanism for regional financial support to prevent or resolve financial crises. This is meant at least to supplement global mechanisms, if not to replace them in certain circumstances. The focus here is on the perceived failures of the International Monetary Fund. It is probably correct to say that there is broad consensus within East Asia that the IMF rescue packages for Thailand, Korea and Indonesia were flawed in terms of their involvement and their conditionality.

One strategic aim of IMF membership for many countries is to secure the interest of the United States and other 'big' countries in their circumstances. This is especially important since capital account crises are now so large that they are beyond the direct resources of the Fund and rely on broader official support through bilateral loans. ${ }^{6}$ Indeed, the IMF normally relies on other international financial institutions and bilateral supporters in its country programs in order to demonstrate wider endorsement of its policy measures. ${ }^{7}$ There is a sense in the region that the IMF was not successful in securing US interest and involvement early enough in 1997. The United States, for example, did not contribute bilaterally to the Thai package, but did later commit to the Korean and Indonesian packages (although the second line of defence was not drawn on in either case). Indeed, the only countries to be involved bilaterally in all three East Asian packages were two regional countries: Australia and Japan.

The other flaw in the IMF packages was the nature of conditionality. There are two dimensions to this. One is that the nature of the crisis was not well identified early enough by 
the Fund. Looking at Thailand, the initial IMF policy diagnosis and assessment were that it was a conventional demand-management problem - excessively easy fiscal and monetary policy and a deteriorating current account - requiring a general policy tightening. But what was happening was not a current account crisis but joint capital account and financial system crises - requiring supportive fiscal policy and not prolonged tight monetary policy. The Fund took a long while to change its view (February 1998 in the case of Thailand), longer than occurred in the region, ${ }^{8}$ and once changed this took a long while to filter through to policy at the national level. The other dimension was the focus on deep and extensive structural reform as part of the conditionality for an IMF package, and the at-times naïve way reform was implemented. ${ }^{9}$ While such reform is no doubt desirable and important, requiring immediate wholesale structural adjustment in an exchange-rate crisis may not be realistic. ${ }^{10}$

Whatever the merit of these criticisms and notwithstanding the fact that many in the region do understand, and were involved in promoting, the use of such packages as a vehicle for pursuing domestic economic and structural reform, the IMF packages and reactions are widely thought to have exacerbated, rather than alleviated, the crisis at critical times in 1997 and 1998. If the global mechanism embodied in the IMF does not work as well as expected and cannot be fully remedied, the view in much of the region is that action also has to be taken at the regional level to prevent and manage financial crises.

The second economic motivation for regional financial arrangements focuses on exchange rate arrangements in East Asia. The causes of the East Asian financial crisis were many, and one aspect that has received considerable attention in East Asia, and Japan in particular, is the heightened vulnerability to external shocks caused by implicit-dollar pegging in a number of crisis-affected economies, notably Thailand but also Indonesia and Korea. ${ }^{11}$

As the dollar appreciated relative to the yen and deutschmark from the mid-1990s onwards, the implicit dollar peg meant that these East Asian currencies also appreciated relative to the yen and deutschmark. The export competitiveness of these countries weakened and their current account positions deteriorated, making them vulnerable to downward pressure on the exchange rate and susceptible to economic and financial shocks and changes in market sentiment. Had these countries tied their exchange rate, even loosely, to a basket peg - meaning some weighted combination of the dollar, yen and deutschmark (now euro) they would have experienced less appreciation of the effective exchange rate and hence been less vulnerable in 1997. 
This is not merely of historical interest. The argument goes that these same countries have now returned to an implicit dollar peg, at least to some extent. ${ }^{12}$ If these countries are not genuinely floating their currencies as they say they are (because of their 'fear of floating'), then the rationale for a basket peg currency arrangement is even greater. Given the rise in intra-regional trade in non-Japan East Asia, some also argue that the weights in the basket peg should be common for the region, or some subset of it. But others fear that a basket peg would be too slow to respond to changes in economic fundamentals and so would be subject to speculative attack.

\section{Strategic factors}

While these economic reasons are important in their own right and warrant serious analysis, they mask the strategic plays by countries in the region. It is much easier and less threatening to use arguments about economics than arguments that make explicit the strategic regional and global positioning involved in the debate about regional arrangements.

\section{Dealing with the United States...}

The central play is directed at the world's sole superpower, the United States. It has the dual aims of using regional arrangements as a bulwark against US economic influence in the region and balancing US influence in global policymaking forums such as the IMF.

Many of the arguments raised about the IMF's performance before and during the East Asian financial crisis are criticisms of US policy and power and how they were exercised. The IMF is widely seen by policymakers and academics in East Asia as a US-run institution: ${ }^{13}$ the United States has effective veto power over key decisions in the Executive Board; the IMF's head office is in Washington DC only a few blocks from the US Treasury; and the powerful First Deputy Managing Director (who does many of the sensitive negotiations) is a US citizen often with close links to the US Treasury.

If the region believed that the United States was sufficiently responsive to its needs and aspirations and that it had an effective voice in the IMF, then the enthusiasm for regional financial arrangements, especially in terms of regional financial cooperation, might be weaker. But it does not.

This needs to be spelled out a bit more. The East Asian financial crisis had a radical effect on the region's perception of the United States as a reliable partner in the domain of 
international finance. The emphasis is intentional. A number of countries regard the United States as their primary partner in security and many regard the United States as a leading partner in trade and investment. ${ }^{14}$ The region recognises and values the unique contribution the United States makes to maintaining security and stability in East Asia. There is no appetite to reverse this. But this does not mean that they are satisfied in all dimensions of international relations. While East Asia is heterogeneous and there are differences of opinion and emphasis between and within countries, the common view in East Asia is that the region was not well served in 1997 and 1998 by its reliance in international finance on the United States. Consider three examples that are in the minds of policymakers in the region.

First, Thailand felt 'betrayed' by the United States. ${ }^{15}$ Thailand allowed itself to be the platform for the United States in the war against communism in Vietnam but the United States did not offer bilateral financing support during the crisis. Indeed the US Treasury was perceived by some in Thailand to be bent on exposing weaknesses in that country even if that meant inducing a crisis in a traditional ally. Thais resented the apparent ready willingness of the United States to help 'bail out' South Korea, which is of clear strategic importance to the United States, but not Thailand.

Second, there is a perception in the region that the United States took advantage of the crisis to undermine Suharto's rule in Indonesia in January 1998 and was willing to do the same in Malaysia to undermine Mahathir later that year. ${ }^{16}$ The United States was seen as being willing to undermine undemocratic regimes even at the risk of great economic and social cost. The robust and fulsome assertion of democracy in Cambodia, Indonesia, South Korea, the Philippines, Taiwan and Thailand in the past few decades shows just how much East Asia values democracy. But the region also places a high premium on political stability, especially in large heterogeneous nations such as Indonesia, and there was deep bewilderment and disillusion with the perceived words and deeds of parts of the US Administration.

Third, countries were upset at the time by the United States' apparent two-faced position on hedge funds. On the one hand, the United States vigorously denied that the New York-based macro hedge funds and proprietary trading desks of international investment banks and securities firms played any particular destabilising role in Asian currency and equity markets in 1997 and 1998, in spite of the size and concentration of those positions and evidence of market manipulation. ${ }^{17}$

But, on the other hand, it organised a bail-out of one hedge fund, Long-Term Capital Management, because of the concern that unwinding that fund's positions could depress US 
financial prices, markets and institutions in September 1998. This sounded a touch inconsistent to East Asians long lectured by the US Treasury and Federal Reserve about the evils of cronyism and dangers of moral hazard; the inconsistency led to talk in the region about the capture of US policymaking by Wall Street.

Some in the region also felt this to be an implicitly racist or at least anti-Asian stance, as discussed below. The 1998 IMF study on hedge funds was also viewed widely in the region as a whitewash of the issues (a sentiment most strongly felt in Malaysia and Thailand). ${ }^{18}$

It is understood in East Asia that US policymaking is divided between the Administration and Congress, and achieving consensus is especially difficult when opposing political parties occupy each seat of power. This was certainly the case in 1997 and 1998: not only was Congress very reluctant to support the Clinton Administration but the antipathy of many members of Congress to bail-outs by the IMF, let alone the United States, was at its peak. The D'Amato amendment, passed by Congress after the Mexico crisis, prohibited the US Treasury from using the Exchange Stabilisation Fund at the time of the Thai rescue package, but had expired by the time of the Korean and Indonesian packages. It may be true that the Administration could not have supported Thailand (and Indonesia) more even if it had wanted to. But to the region, this just shows more starkly the unreliability of existing mechanisms and the consequent need for some sort of additional regional mechanism.

These criticisms are made notwithstanding the region's recognition of the central importance of the United States in the world economy and the fact that sustained strong US economic growth in the aftermath of the crisis provided much-needed external demand for Asian goods and services. While the increase in the US current account deficit at the time was welcomed in East Asia, it is viewed in the region as more the outcome of US policymakers letting their own economic expansion continue to run than an explicit decision to underpin East Asia's economies. The fact that US economic growth helped underpin East Asian growth was a happy coincidence.

The challenge for the region is how to maintain US economic and strategic involvement in East Asia but at the same time secure the sort of engagement in international financial policymaking that it wants from the United States. One way to do this is to emphasise that economic prosperity and security in East Asia are unambiguously in America's interests, and that, consistent with the policy aims of the Bush Administration, ${ }^{19}$ it is time for the region to be more self-sufficient in providing a market-oriented economic and financial infrastructure for itself. The regional financial architecture should be marketed as an example of East Asia 
being willing to take on its financial responsibilities, and that the possibility of overlapping regional and global institutions or frameworks should be seen constructively as a device for avoiding excessive concentration of power in one institution. ${ }^{20}$

The sense after the crisis that the United States was an unreliable partner in matters to do with international finance spilled over automatically into disillusion with the IMF. The region does not feel that it can exercise its voice within the IMF, and so the region's 'problems' with the Fund cannot be readily addressed through normal processes.

There is a strong feeling in the region that it is wronged by the under-representation of Asia and over-representation of Europe in the Executive Board of the Fund. ${ }^{21}$ There is little expectation of remedying this: why would the Europeans, especially the small countries, ever agree to reduce their influence? Japan also feels excluded from the US-Europe 'agreement' that the Managing Director of the Fund be European and the First Deputy Managing Director be American. Japan's nomination of its former Vice-Minister for International Finance, Dr Eisuke Sakakibara, as a candidate for Managing Director in 1999 was an assertion of its discontent.

There is also a sense in non-Japan East Asia that one reason the United States has been able to dominate the IMF and other forums is because in the past Japan has not spoken up for the region as loudly as it could have. Observers of the IMF note that one aspect of the Fund is that it is a device for the major economies to champion the interests of their regions. The United States and Europe have long been robust supporters in a range of forums for Latin America and for developing central and eastern Europe and North Africa, respectively.

But Japan is not seen as having done this to the same extent for East Asia. Whatever the reasons - the legacy of colonialism and war, Japan's dependence on US security, a preference for consensus, the diversion of policymakers' focus to domestic economic problems - the result is that East Asia's champion has let itself be squeezed out. This has certainly started to change in the past few years but requires effort and persistence to remedy. There are also concerns that Japan's focus on regional financial architecture signals that it is less prepared to work toward reforming global forums and representing the region's interests in them.

\section{$\ldots$ and asserting national interests}

But the strategic play is not only about giving the region a stronger voice in global affairs and limiting the hegemony of the United States. It is also very much about who has a voice and perhaps the strongest voice in regional arrangements. In other words, the play is not just about 
limiting the influence of the United States in the region but also about asserting a country's own influence at the same time.

The interests of countries in the region vary but they tend to coincide in the promotion of regionalism and its embodiment, regional financial cooperation. Take three examples: Japan, China and the Association of South East Asian Nations (ASEAN).

Japan is concerned with its place in the world. The 1990s have had a profound effect on that country's self-confidence. At the end of the 1980s, Japan felt that it was poised to become the world's leading economy: its assets were highly priced, its banks looked like they were about to dominate world finance, and its manufacturers were leading global industrialisation. The collapse of its asset price bubble and world financial empire, and a decade of stagnation and recession have undermined its confidence in its ability and its future. The dominance of the dollar, the introduction of the euro and the deepening of European economic and financial integration have left Japan with a deep sense that it is losing its place as a key G-3 economy. At the same time, the rise of China leaves it with the fear of losing its economic pre-eminence in East Asia.

This has meant that Japan has tried to assert a greater role in regional infrastructure. The Miyazawa plan for the recovery of crisis-affected economies, the proposal for an Asian Monetary Fund, the proposal for a common-basket exchange rate peg arrangement for some ASEAN countries, and the detail of the ASEAN+3 (China, Japan and Korea) swap agreement made in Chiang Mai, Thailand, have all been led by Japan. ${ }^{22}$ These ideas have been proposed and argued on their perceived merits but they also meet Japan's strategic aim of entrenching itself permanently as the centre of regional arrangements.

The basket peg arrangement, for example, has been proposed as a way to minimise the effects of volatility in the G-3 countries' exchange rates on developing East Asia. But it is also anticipated that one effect of the arrangement - greater stability against the yen - will encourage more trade, investment and financial transactions to be conducted in yen. That is, it supports Japan's commitment to internationalise the yen, commensurate with its status as a G-3 economy.

China is also aware of its growing status in the regional and world economy. While China opposed Japan's proposal in 1997 for an Asian Monetary Fund, largely because it was suspicious about Japan's motivation, it has since supported (or at least not vetoed) greater regional financial cooperation. China has judged that such cooperation is not only a useful balance against US financial power but enables it to secure a stronger strategic position at the 
centre of the region. China's proposal to join the ASEAN Free Trade Area (AFTA) is part of this play for greater political influence in the region.

Regional cooperation, especially through the ASEAN+3 grouping, also provides China with a valuable forum for dialogue with Japan and Korea through additional bilateral and trilateral meetings on the fringe of the ASEAN +3 meetings. The +3 (that is, China, Japan and Korea) dialogue is also seen as a major advantage from the viewpoint of Japan and Korea, and was a primary goal in setting up ASEAN+3.

From the ASEAN point of view, these regional arrangements are a substantial advance in outside recognition of ASEAN as a political entity, rather than merely as another collective expression for Southeast Asia. Aware that they are 'small' relative to the big economies of Northeast Asia, the ASEAN countries are keen to develop a subregional entity that can have more weight in dealings with the 'big three'. ${ }^{23}$

The promotion of these varying strategic interests within East Asia has gravitated toward a common agenda for stronger regional arrangements, financial and otherwise. While it means that there is now genuine support for deeper cooperation and integration in East Asia, it does reveal two vulnerabilities (which are not necessarily unique to the region). First, a consensus that is based on reconciling competing strategic interests means that agreed outcomes tend to the lowest common denominator. As will be discussed later in the paper, reaching agreement has been time consuming and progress has been modest. Second, the consensus is vulnerable to changes in how countries, especially the key players, perceive their strategic interests. This is not to say that arrangements made so far will come undone but it does mean that the path forward is not fixed; it could advance rapidly and substantively or it could not progress further for a while.

\section{Chauvinistic motivation}

Given the tumultuousness and nature of events in the past few years, it is not surprising that there has also been a chauvinistic and emotional element in the development of East Asian regionalism. This was most intense during and immediately after the crisis, but it still persists to some degree.

The crisis damaged the region's confidence and ego, not only by the terrible economic and social damage it caused but also by the exposure of flaws in domestic systems and policies and the reliance of the region on outside influences, especially the United States and the IMF. The 
ability of the region to come together so quickly and fulsomely to support Thailand (when the United States refused to) is a matter of regional pride. But parts of the region also feel shame that it did not have the comprehensive internal resources and wherewithal to deal with the crisis on its own, as the Europeans did in $1992 .{ }^{24}$ The desire to both feel and assert a confident and capable East Asian identity is strong and is the rallying cry for building regional institutions.

The emotional intensity of this desire was exacerbated by the interaction between East Asian and US policymakers during the crisis. The sense in East Asia was that US and other Western policymakers regarded East Asia's commitment to market-oriented economic and financial processes as weak. The region felt that its policymakers were viewed by outsiders as relatively unreliable, opportunistic, inferior and incapable.

An example of this is the assessment by Eichengreen and Bayoumi (1999: 361-64) that East Asia does not meet the necessary intel lectual preconditions for regional integration. They argue that, in Europe, 'the ideal of integration is intimately connected with the liberal and democratic principles of the Enlightenment and has roots in centuries of history ... by 1945 the intellectual preconditions for European integration were in place', to be ignited by the 'spark of the Marshall Plan' into a regional commitment and agenda to cooperate at the deepest levels, including the unprecedented action of granting supranational authority to regional entities.

They argue that East Asia could not be more different. Not only does the region lack the necessary 'political solidarity and cohesion', but internal resistances to integration in East Asia are substantial and overwhelming. In the case of Europe, such resistances were 'overcome partly by the intervention of an outside agent, the United States' but this is missing in East Asia's case. They characterise East Asia as dominated by a colonial and insular military tradition, ideological conflict (communist China versus market-oriented economies elsewhere), and a complete unwillingness to allow outside parties to interfere in domestic affairs.

Indeed, they go on to say that East Asia is inherently incapable of substantive regional integration:

At a deeper level, East Asia lacks a Benthamite/Rousseauan/Saint-Simonian heritage of collective democratic governance through integration, As Katzenstein puts it, 'the notion of unified sovereignty ... central to the conception of continental European states, does not capture Asian political realities.' As in China today, the regions resist the attempts of the center to exercise its politics through the operation of political and legal institutions. The idea of a centralized state with a monopoly of force that regiments its citizens through the 
superimposition of a common set of institutions is a European conception, not an Asian one. Asian civil society is structured by ritual, ceremony, and economic networks more than by military force or the rule of law. The notion of strong, cohesive nation-states in the Western mode being foreign to Asia, it is unrealistic to speak of pooling national sovereignties which do not exist. (Eichengreen and Bayoumi 1999: 363)

This type of assessment has not been well received in East Asia. ${ }^{25}$ It is seen as a selective and glorified reading of European history and an assertion of European superiority. It is also seen as a subjective caricature which is far removed from the reality of modern East Asia. It is intellectually flawed in its assertion that there is only one institutional route to integration the European way of creating (what are viewed from the outside as bloated, self-interested, poorly governced) regional bureaucracies, rather than regional cooperative policymaking supported by flexible secretariats. While there is no doubt considerable work to be done in strengthening markets and policy dialogue and cooperation in the region, it is wrong to say that it cannot be done in East Asia.

The nature of cross-Pacific dialogue has also encouraged Asian chauvinism. At times, US officials and economists have talked down to and hectored their East Asian colleagues. ${ }^{26}$ And at times, they have delivered their message aggressively. This has created bad feeling and been counterproductive to the willingness of the recipients to accept - and be seen to accept - the message, even if they agree with its substance.

\section{The policy agenda}

Dissatisfaction with the international and regional financial architecture after the crisis has set off a new program for integration and cooperation in East Asia. This has three main elements: policy dialogue, financial cooperation and common currency arrangements. Consider these in turn.

\section{Policy dialogue}

The crisis revealed a number of weaknesses in the structure and nature of official policy dialogue on economics and finance in the region. Most strikingly, it showed the lack of a regional forum for comprehensive and substantive discussion of economic and financial issues and for the advancement of regional interests in global forums and institutions. 
The need for such a forum is largely viewed as self-evident in the region. In the first place, it brings policymakers together at the political and official level to talk, develop trust, and assess the economic and policy structures in place. It allows consensus views to be formed (or not, as the case may be) and for these to be presented beyond the region.

A regional forum could play an important role in expressing the region's views in global forums and in defending the region's interests in international policymaking. This is important because other regions - Europe, the Americas, Africa and numerous sub-continental groupings - have at various times used their group to increase their influence. Indeed, it is difficult to see how other regions could oppose the principle of enhanced regional policy dialogue in East Asia when they have they themselves use their own groupings to influence policy. ${ }^{27}$

A regional policy forum can also deepen outsiders' understanding of the region. Region insiders have a comparative advantage over region outsiders in understanding the structure and operation of economies and policy structures in the region; it is hard to dispute the claim that the deepest understanding of the East Asian economies resides in East Asia, not the United States or Europe.

A number of forums for officials from East Asia to meet and discuss issues of common concern were in place well before the crisis, including meetings of the Asia Pacific Economic Cooperation forum's finance ministers and officials, ASEAN finance ministers and officials, the EMEAP (Executives' Meeting of East Asia-Pacific Central Banks) central bank governors, deputies and officials, and the Four Markets Meeting. Table 1 provides a summary. Some forums, such as APEC, have comprehensive regional participation and also include countries outside the East Asian region. The coverage of these policy forums also varies. APEC and ASEAN finance ministers cover a wide range of economic and financial issues in their meetings. Others are more specialised: EMEAP is focused on central banking matters (such as financial markets, payments systems and banking supervision) and the Four Markets Meeting is focused on financial markets and institutions.

But none of them meets the need of East Asia for a regional forum that is comprehensive in membership and coverage, discusses the key issues in a substantive and frank manner, and has the strong political support essential to influencing global institutions and policymaking.

APEC, for example, is a useful forum for identifying agreement and commitment in the Asia Pacific region and for commissioning policy work and analysis. But its size makes it less useful as a forum for informality and extended negotiation, and the inclusion of the United States and others means that it is not an East Asian forum. The smaller specialist forums, such 
Table 1 Forums for economic policy dialogue in East Asia

\begin{tabular}{|c|c|c|c|c|}
\hline Group & Established & Members & Authorities & Coverage \\
\hline APEC & $1989 / 95^{1}$ & $\begin{array}{l}\text { Australia, Brunei, Cambodia, } \\
\text { Canada, Chile, China, } \\
\text { Indonesia, Japan, Korea, } \\
\text { Laos, Malaysia, Mexico, } \\
\text { Myanmar, New Zealand, } \\
\text { Peru, Philippines, Russia, } \\
\text { Singapore, Thailand, United } \\
\text { States, Vietnam }\end{array}$ & $\begin{array}{l}\text { Ministries of } \\
\text { finance and } \\
\text { central banks, } \\
\text { IMF, World } \\
\text { Bank, Asian } \\
\text { Development } \\
\text { Bank }\end{array}$ & $\begin{array}{l}\text { All economics } \\
\text { and finance }\end{array}$ \\
\hline ASEAN & 1967 & $\begin{array}{c}\text { Brunei, Cambodia, } \\
\text { Indonesia, Laos, Malaysia, } \\
\text { Myanmar, Philippines, } \\
\text { Singapore, Thailand, } \\
\text { Vietnam }\end{array}$ & $\begin{array}{l}\text { Ministries of } \\
\text { finance and } \\
\text { central banks }\end{array}$ & $\begin{array}{l}\text { All economics } \\
\text { and finance }\end{array}$ \\
\hline ASEAN+3 & 1999 & $\begin{array}{l}\text { Brunei, Cambodia, China, } \\
\text { Indonesia, Japan, Korea, } \\
\text { Laos, Malaysia, Myanmar, } \\
\text { Philippines, Singapore, } \\
\text { Thailand, Vietnam }\end{array}$ & $\begin{array}{l}\text { Ministries of } \\
\text { finance and } \\
\text { central banks }\end{array}$ & $\begin{array}{l}\text { All economics } \\
\text { and finance }\end{array}$ \\
\hline EMEAP & 1991 & $\begin{array}{l}\text { Australia, China, Hong Kong } \\
\text { SAR, Indonesia, Japan, } \\
\text { Korea, Malaysia, New } \\
\text { Zealand, Philippines, } \\
\text { Singapore, Thailand }\end{array}$ & Central banks & $\begin{array}{l}\text { Financial } \\
\text { markets, } \\
\text { payments } \\
\text { system, bank } \\
\text { supervision }\end{array}$ \\
\hline Four Markets & 1992 & $\begin{array}{l}\text { Australia, Hong Kong SAR, } \\
\text { Japan, Singapore }\end{array}$ & $\begin{array}{c}\text { Ministries of } \\
\text { finance and } \\
\text { central banks }\end{array}$ & $\begin{array}{c}\text { Financial } \\
\text { markets }\end{array}$ \\
\hline $\begin{array}{l}\text { Manila } \\
\text { Framework } \\
\text { Group }\end{array}$ & 1997 & $\begin{array}{l}\text { Australia, Brunei, Canada, } \\
\text { China, Hong Kong SAR, } \\
\text { Indonesia, Japan, Korea, } \\
\text { Malaysia, New Zealand, } \\
\text { Philippines, Singapore, } \\
\text { Thailand, United States }\end{array}$ & $\begin{array}{c}\text { Ministries of } \\
\text { finance and } \\
\text { central banks, } \\
\text { IMF, World } \\
\text { Bank, Asian } \\
\text { Development Bank }\end{array}$ & $\begin{array}{l}\text { Economic } \\
\text { surveillance } \\
\text { and } \\
\text { technical } \\
\text { cooperation }\end{array}$ \\
\hline
\end{tabular}

Note: 1 APEC trade ministers first met in 1989 but APEC finance ministers first met in 1995.

as EMEAP and the Four Markets Meeting, include only regional economies, but their role is in promoting specialist discussion in the region. They also tend to be removed from the political process: being 'outside' the political orbit means that they can more readily concentrate on 
issues of policy substance rather than political form, but they also then tend to lack direct political influence and support.

Two new forums for policy dialogue were established as a result of the crisis. The Manila Framework Group (MFG) was established in November 1997 by a number of APEC members to progress financial cooperation and surveillance in East Asia. The MFG is designed as a mechanism for regional surveillance, economic and technical cooperation, strengthening the IMF's capacity to respond to financial crises, and developing a cooperative financing arrangement to supplement that of the IMF. ${ }^{28}$

By the end of 2001, there had been nine meetings of the MFG. Participants say that the value of MFG lies in the frankness and coverage of dialogue between policymakers. But many participants also feel that the discussion is one-sided, in the sense that they are subject to scrutiny by the United States and the IMF but not the other way round. And the participation of the United States and Canada means that the group does not meet the aspirations of East Asia for a separate regi onal forum. The MFG has not been at the forefront of regional thinking about cooperative financing arrangements: it has considered the development of cooperative financing arrangements in the past few years but ASEAN+3 remains the preferred focus of most participants. ${ }^{29}$

The ASEAN+3 heads of state first met as such on 28 November 1999 and issued a 'Joint Statement on East Asia Cooperation', calling for strengthened policy dialogue and collaboration, among other things. ${ }^{30}$ The value of ASEAN +3 is that it is closer to being a regional forum and has strong political support. But it is still in its early days. Participants say that it is yet to achieve the openness and coverage in discussion that characterises other policy forums. And its regional coverage is not uniform, in the sense that it does not include such regional economies as Taiwan, Hong Kong SAR, Australia and New Zealand.

For greater financial collaboration in the region to be effective, it must be associated with improved policy dialogue and a willingness to frankly discuss key issues, including the policy stance and state of play in member economies. The tradition of not interfering in the domestic policies of countries in the region, especially in ASEAN but also in China, is a challenge to building effective meaningful policy dialogue in East Asia. But it is one that is on the minds of policymakers and more thought is being given to ways to improve the effectiveness of dialogue.

There is interest in looking at the experience of other regions in building up policy dialogue, as shown by the discussions between East Asia and Europe in ASEM. The European 
experience does shed some light. ${ }^{31}$ For example, developing and maintaining close working relationships between policymakers has been important in promoting effective policy dialogue in Europe. ${ }^{32}$ Policy meetings in Europe in the first few decades of the post-war period were dominated by many of the same people, and this served to promote effective working relations, trust and a common vision. In this respect, duplication and overlap in forums, especially at early stages of region-building may useful for building up trust.

One feature of the dialogue forums that 'worked' in Europe was that the chair of the forum did not rotate between members (every six months in the typical pattern) but was fixed for a relatively long period of time. Another feature that 'worked' in the Organisation for Economic Cooperation and Development has been the use of an independent outside chair, namely the IMF chief economist, to open and lead discussion on economic and financial issues. It may also be the case that widening the membership to other economies in the region may change the dynamics of policy dialogue, as well as make it fully representative of the East Asian region.

Building up well-functioning forums for policy dialogue can take a long time. It is not a linear process and it is unreasonable to expect perfection at the start. Europe's experience in building regional policy dialogue was piecemeal and iterative. Policymakers were opportunistic in the sense that they took advantage of opportunities to strengthen dialogue when they arose. The approach in East Asia has been, and is most likely to continue to be, similar in this respect. The process is likely to be messy, with progress going back and forth. But it is now underway and the commitment to it is strengthening.

\section{Financial cooperation}

The financial crisis led to a deep shift in the thinking within the region about the need for substantive forms of regional financial cooperation. The disillusion with the Fund's performance during the crisis has meant that some reliance on regional mechanisms is inevitable. This has been underpinned by high expectations but poor progress in international forums in dealing with key issues about the international financial architecture that are important to East Asia, such as private sector involvement, highly leveraged institutions and destabilising speculation, and reform of the IMF. ${ }^{33}$

One purpose of strengthening policy dialogue in East Asia has been to determine the structure, conditions and eligibility criteria for regional financial cooperation. The ideas have ranged anywhere between the two extremes of no regional financial architecture, with only a 
reliance on IMF facilities and the New Arrangements to Borrow (NAB), to only a regional architecture for financial support, thereby dropping the IMF out altogether.

\section{What is financial cooperation?}

The debate and policy action are still at a relatively early stage. In part, this is because policymakers are still coming to grips with the aims of regional cooperation. Financial cooperation, be it regional or global, can be of three broad types. It can be a mechanism for providing very short-term temporary liquidity support, say because of a mismatch in funding. ${ }^{34}$ The amounts in this case are likely to be small.

Second, it can be a device for preventing crises. A financial crisis is more likely to occur when economic fundamentals and financial structures are weak, so much of the work on crisis prevention has focused on reducing domestic vulnerabilities, as reflected in the IMF's focus on developing and implementing standards for reporting and policy.

Crisis prevention measures also include making more funds available to deal with crises. In standard models, strong fundamentals are associated with the stock of foreign currency reserves. ${ }^{35}$ Building up the armoury of reserves through access to IMF facilities or bilateral swap arrangements - which are essentially one country lending its foreign exchange reserves to another - can be a device to prevent a crisis from occurring. This is most likely to work in a country where the economic fundamentals are sound, so that the signal that the increase in reserves gives about the fundamentals is an accurate and credible one. The amounts required in this case are likely to be large.

There is another, more recent dimension to financial cooperation to prevent crisis prevention: contagion. Even countries with fairly sound economic and financial structures may be adversely affected by changes in investor and speculator sentiment owing to weakness in another country. ${ }^{36}$ The possibility of contagion led the IMF to establish a new lending facility in 1999, the contingent credit line (CCL), which is available to countries in good economic condition that experience investor reversals because of a crisis elsewhere.

Third, financial cooperation can be directed toward resolving a financial crisis once it has begun. In this case, credit is provided to a country to boost its reserves to meet international payments, subject to conditions set by the lender. This sort of financial cooperation is designed to restore market and investor confidence and underpin economic recovery. This is standard IMF fare and, as shown by the financial crises in 1994, 1997 and 1998, the amounts required are likely to be large. 


\section{Should financial cooperation beregional or gl obal?}

The substantive issue facing East Asia is how regional financial cooperation fits in with multilateral mechanisms centred on the IMF. Is regional cooperation designed to provide temporary liquidity support, prevent financial crises or help in the resolution of these crises once they have begun? The merits of regional, as opposed to global, mechanisms need to be spelled out with respect to each of these types of financial cooperation.

The simplest case of financial cooperation is the provision of short-term liquidity support to cover a temporary shortfall in funds. This type of funding is not generally provided by the $\mathrm{IMF}^{37}$ and is typically provided by regional networks, such as through bilateral or regional swaps. In this respect, there is no inherent tension between regional and global liquidity support arrangements. In fact, well-structured regional arrangements are important because they reduce the risks of a crisis caused by a short-term liquidity shortfall. Moreover, the policy dialogue that accompanies these arrangements helps increase intra-regional understanding of economies and markets.

The more complex cases are the crisis prevention and resolution processes. At the risk of oversimplification and caricature, there are three standard arguments against regional processes in East Asia for financial cooperation.

\section{The primacy of global cooperation}

The first argument is that regional financial support mechanisms weaken the global mechanism because of regulatory arbitrage. If the terms and conditions of the regional support mechanism differ from those of the IMF facility, then borrowers will seek the loan with the best terms (such as a lower interest rate and longer repayment schedule) and easiest conditions (less requirement to implement reforms, easier policy stance). If the terms and conditions are easier on regional loans than on IMF loans, ${ }^{38}$ then there will be a general weakening of conditionality and a drift away from the IMF and global cooperation. A subsidiary argument is that when crises occur across a number of regions, the costs of coordination and risk of inconsistent outcomes are higher.

The counterargument made in East Asia proceeds as follows. The starting premise is different: there should be no presumption that a global arrangement is better than a regional arrangement in all cases. The criterion to judge which arrangement is better is that which best achieves the aim of preserving stability, not whether it is global or regional. For example, if the terms and conditions set by the IMF are inappropriate while those set by the regional body are 
appropriate, then the regional arrangement is preferred, all else given. And as for argument that it is easier to preserve consistency at the global level, it is hard to make the claim that the IMF stands above political pressures and is always consistent in its programs.

These are reasonable counterarguments. It cannot be assumed that regional arrangements in East Asia would be inherently worse than IMF arrangements: it ultimately depends on how the institutions and instruments of cooperation are organised in practice. There are five dimensions to this.

First, the crucial issue is whether regional or global frameworks have a comparative advantage in delivering appropriate conditionality. There is no doubt in most people's minds that the IMF made serious errors of judgement in the East Asian crisis. This is well-worn ground. The issue from here on in should not be payback: the past is past. It should be whether the IMF is more likely to repeat the same kind of mistakes again in the future and whether a regional arrangement is likely to do any better. Frankly, this is impossible to answer since it depends on too many unknown factors.

One factor is the level of knowledge and understanding about East Asian economies, markets and political processes. There is considerable technical knowledge, data and analytical power at the Fund but this does not mean that it has a solid understanding and experience with economic, institutional and market processes in the region. This sort of knowledge is generally found at the national and regional level.

The issue then is whether the regional body has sufficient expertise, experience and 'distance' to marshal the resources, frame the conditions of the package and negotiate with the borrowing country. Moreover, the IMF has broad and extensive experience when it comes to dealing with financial reform after a crisis and facilitating the write-down of existing debt; more than a regional body ever could. The conundrum is that the IMF may be more likely to be able to impose policy conditions in a package and provide expert advice in resolving the crisis than a regional body, but that the regional body is likely to better understand the economy, institutions and markets.

Another factor is the nature of the institution making the decision. One criticism of the Fund is that its view of the world - how it interprets a crisis and the policy that it recommends - changes slowly. This is exacerbated by its bureaucratic structure and size: the institutional view is a highly persistent reaction to the past. A regional institution that is less bureaucratised (like a secretariat) may be more flexible. The approach taken also depends on the intellectual bias or culture of the institution. Some criticise Fund economists as being too ideological and 
fundamentalist about markets. But the criticism of a regional body is that its intellectual culture may overstate the institutional differences in Asia at the expense of economic forces. There is also the problem of whether a large regional body would be able to attract the quality of staff and policy formation that global institutions such as the IMF and World Bank can. ${ }^{39}$ Another factor is whether countries are more likely to take ownership of reform if it comes from within the region or without. These are clearly open questions.

Second, regional arrangements are adequate if there are sufficient pressures in place to ensure that the public monies used to fund regional financial support are responsibly allocated - in short, that they are provided subject to terms and conditions. It would seem, on balance, that sufficient pressures do exist in East Asia. Most countries in the region are democracies and policymakers are sensitive to their civic responsibilities and pressure from the electorate, especially after the large-scale exposure of official corruption and featherbedding in recent years.

The likely lender countries - China, Japan and Korea - have no appetite for wasting their own funds, as shown by the strict terms and conditions that they have attached to the network of ASEAN+3 bilateral swaps (discussed below). The public in many countries is not prepared to accept it. The public mood against bank bail-outs in Japan, for example, has made politicians unwilling to use public funds to buy out banks' bad debts: they are not going to tolerate their money being used to bail out some other country.

Third, the relative merit of global and regional mechanisms depends on the effectiveness of governance over the lending intermediary - the IMF at the global level and, say, an Asian Monetary Fund at the regional level. It is not clear which provides the best governance mechanism. Governance by member governments of IMF staff and management through the Executive Board is weak. ${ }^{40}$

The role of East Asian governments in the governance of the IMF is also weak. This is in part because the voting power of Fund members and constituency representation on the Executive Board is biased toward Europe, the Middle East and Africa, at the expense of East Asia, especially Japan. But it is also because some East Asian countries do not take advantage of their position to be actively involved and to lead discussion in meetings, for any number of reasons - resentment, a distaste for directness or confrontation, relatively poor English language skills, a poor grasp of the issues, or a reluctance to take a global rather than regional or national perspective. ${ }^{41}$ 
Whether governance would be better at the regional level is an open question. It depends on some critical factors. If regional arrangements are centred in a large bureaucracy with policymaking powers (akin to the IMF), then the institution is likely to be harder to govern by national governments. If it is more like a well-run secretariat (perhaps akin to the way Andrew Crockett runs the Bank for International Settlements), then governance and control of policy are easier since policymakers at the national level retain control over the policy agenda and its implementation. East Asian policymakers are much more inclined to secretariat-type regional institutions. On the other hand, effective governance also requires policymakers to participate actively and openly in governing forums.

Fourth, the ability of an institution to garner broader international interest and support is a crucial element in organising a rescue package. The IMF failed to gain additional support from the United States for bailing out Thailand (or Indonesia). This weakened the credibility of the program and was the impetus for Japan's proposal for an Asian Monetary Fund in September 1997. A regional fund is one way to lock in regional support. And it may also be a high-profile device to influence the IMF and other country lenders.

Fifth, regional lending facilities may in fact be more effective than global arrangements in preventing crises because of contagion. The IMF's Contingent Credit Line (CCL) facility was designed to prevent contagion: a country with reasonably good fundamentals would sign on to the facility to boost its reserves in the event of financial contagion. But it has not been activated since it was introduced in 1999. There are two main reasons for this. In the first place, countries that meet the entry criteria are concerned that signing up to the facility would send a bad signal to financial markets, force up borrowing costs and even start a crisis. They are also afraid that exiting the facility, especially if they are forced to because they no longer meet the entry criteria, would create a loss of market confidence in them and also create a crisis. The problems with the CCL are the signals created by entry and exit, rather than the facility itself.

A regional financial arrangement that is available to members when they face contagion may overcome this problem. There would be no adverse signal from entry or exit since there would be no entry or exit from access to the facility: funds could be disbursed immediately on approval by the regional body (and at the discretion of the regional body). The credibility of the facility would depend on the credibility of the regional body. One way of acquiring credibility would be to allow for the IMF to make a statement of support of the regional action, if it considered this to be appropriate. 
Put together, these five considerations suggest that there is a complementarity between global and regional arrangements. On the one hand, global arrangements allow policymakers to deal consistently with crises. They create distance between the borrower and lender so the risk of the lender being 'captured' by the borrower is smaller. And international institutions have the requisite expertise to deal with the aftermath of a crisis. On the other hand, the best understanding of countries in a region resides in the region. Regional arrangements are more likely to prevent countries slipping through the global net because they are not important enough to the United States or Europe. And preventive arrangements at the regional level might be more effective than those at the global level, such as the CCL.

This goes some way to addressing the question implicit in this analysis of whether an Asian Monetary Fund could have dealt better with the crisis than the IMF. ${ }^{42}$ It is a natural question to ask but it is also a nonsense question because the counterfactual is unknowable. There is no way of providing a firm answer one way or the other.

The crisis could have been handled better. There is widespread agreement that the Fund made some serious errors in terms of judging the nature, effects and severity of the crisis, and that the policy recommendations to deal with it, including tight fiscal and monetary policies and excessive focus on structural defects in the economy in an exchange rate crisis, were flawed. Others, including in the private sector, also made these mistakes.

But could regional policymakers left to their own devices have done better? The exchanges between officials in the region and those at the Fund and elsewhere outside the region are not on the public record. But those involved say that there were serious representations from senior officials within the region to those outside the region about these matters from the start of the crisis. If these views had influenced thinking outside the region, the effects of the crisis may have been dampened. If there had been a regional fund, and if this perception had influenced its thinking, then things may have been better.

But new problems could have arisen, especially if only a regional fund were involved such as resource constraints in a widespread regional crisis, a lack of expertise in the region to deal with the financial and institutional problems, and the difficulty of involving privatesector institutions from outside the region (such as US and European banks) in crisis resolution. The set of criticisms in the counterfactual may have been very different. 


\section{Resource constraints}

The second argument against regional financial cooperation is that the region would not have the resources to deal with a region-wide shock because countries will need their own reserves and will not be able to share them. If all countries are affected or if a major financial shock were to hit the principal lenders in the region and limit their ability to lend, then the regional arrangement may not work.

The counterargument made in East Asia is that this means that global arrangements and regional arrangements must be complementary. It is not a case of 'either or'. In some situations, a regional response may be appropriate and in some cases, such as a major regional or cross-regional crisis, a global response through the IMF would be appropriate. Even in the latter case, coordinated regional support as a first or second line of defence may be important in putting an adequate financing package together. ${ }^{43}$

\section{Inadequate policy dial ogue}

The third argument against regional support arrangements is that the level of policy dialogue needed to underpin successful financial cooperation is too weak in East Asia. Countries in the region are not willing to expose themselves to surveillance and monitoring of domestic economic conditions and policy by their peers. This is particularly so with ASEAN's policy of non-interference in its members' domestic affairs, including in both public and private discussion.

This judgement was probably right a few years ago but views are starting to change. Policymakers understand that policy dialogue in the region has to be strengthened and improved, and there is now increasing political will to do this. They also realise that progress will be piecemeal, uneven and iterative - it is unreasonable to expect all the pieces to be in place immediately.

Whatever the case, the real test of any regional arrangement will be in how it performs in future financial crises. There are arguments for and against regional financial arrangements of various sorts and it is not possible to conclude which is right on the basis of the arguments alone. Global and regional cooperation can be effective and stabilising or ineffective and/or destabilising. It really depends on how arrangements are implemented.

The effectiveness of financial cooperation at both the regional and the global level depends in part on how cooperation is structured. This includes not just the terms and conditions of the support lending, but also the institutional and dialogue forms in which it is 
activated. In practice, the evaluation of the instruments cannot be isolated from the institutional structures in which they are nested.

As a final comment, the success or otherwise of regional financial cooperation should be measured by how the regime as a whole prevents or resolves future financial crises in East Asia. The focus should not be whether regional mechanisms and institutions are established. Minimising crises is the matter of substance; creating mechanisms is a matter of form.

One hope of the talk and action on regional policy dialogue and financial cooperation is that it will influence global policy dialogue and financial cooperation. A new entrant makes the 'market' for dialogue and cooperation contestable and may change the reaction of incumbents. The formation of regional dialogue and cooperation was driven by deep dissatisfaction with the IMF's performance in 1997 and 1998 and the perception that US support is unreliable. The development of regional processes is partly aimed at changing the reactions of the IMF and other countries to make them consider the characteristics and needs of the region, and recommend and apply appropriate policies. But the 'threat' of entry is probably not sufficient to do this; actual entry may be required to change the reaction of the IMF and major countries outside the region.

\section{Thestate of play in financial cooperation in East Asia}

The first proposal for greater regional financial cooperation as a result of the crisis occurred fairly early, when Japan proposed an Asian Monetary Fund in September 1997. Japan was willing to commit half of the proposed US $\$ 100$ billion to set up the fund. This proposal soon failed in the face of opposition by the United States, because of perceptions that it would undermine the IMF, and China, because it was suspicious of Japan's intentions. ${ }^{44}$ What has eventuated so far in terms of financial cooperation has been much more modest.

There have been two developments in regional financing initiatives since 2000, both under the umbrella of the Chiang Mai Initiative (CMI) of May 2000. The first is the expansion of the ASEAN swap arrangement established in August 1977. Under this arrangement, the five original ASEAN members agreed to provide up to US $\$ 40$ million to other members. This amount was obviously too little to be of help except for minor liquidity shortfalls. It has been used only four times and was not called upon in the 1997-98 financial crisis. ${ }^{45}$ The ASEAN swap arrangement was widened to all ASEAN members and increased to US $\$ 1$ billion in May 2001. The expanded arrangement is still too small to deal with financial crises but can be used for liquidity shortfalls. 
The second development is the establishment of a full series of bilateral swap and repurchase agreements between the ASEAN+3 countries. The network of bilateral swaps in ASEAN+3 will be fully in place by mid-2002. The bilateral swaps are secured by government guarantees and range in amounts of US $\$ 1$ billion to US $\$ 5$ billion, and total around US $\$ 30$ billion. Ten per cent of the swap can be allocated on the discretion of the lender and the remaining 90 per cent is allocated on the discretion of the lender and is subject to the borrowing country meeting IMF conditions for financing. ${ }^{46}$ The swaps can be rolled over a specified number of times and the borrowing country is required to provide additional information regularly to the lending country.

In its current state, the CMI is far too small to be directed at crisis prevention or crisis resolution by itself. The total size of the bilateral swaps may sound large but, compared with the capital flows and size of speculative positions in place in 1997 and 1998, it is not. ${ }^{47}$ The short positions on the baht alone in mid-1997, for example, were about US $\$ 27$ billion, the size of the Bank of Thailand's foreign exchange reserves. The size of the short positions on the Australian dollar, Hong Kong equities and Hong Kong dollar, New Zealand dollar, ringgit and Singapore dollar in mid-1998 are thought to have been roughly about US $\$ 47$ billion. The size of the short positions on the yen in mid-1998 are thought to have been between US\$200300 billion. And the size of these positions was endogenous to the exchange rate policy and level of reserves at the time. ${ }^{48}$

The CMI in its current form can be used in conjunction with an IMF facility to minimise a financial crisis. And it can be used by itself to fund a temporary shortfall in liquidity between a member country, which may help avoid a crisis. The CMI is widely seen as only the first step in the process of regional financial cooperation and is due for review by ASEAN+3 in 2004 .

The target of a number of countries is to create an Asian Monetary Fund-type institution that could be a first port of call in dealing with financial crises within the region. For most, if not all, countries, an AMF is seen as complementary to the IMF's regional and global responsibilities but would also be independent of the IMF. It is widely recognised that an AMF will take time to develop and that progress toward it is not likely to be smooth since it depends on the sustained convergence of competing strategic interests in the region and the formation of consensus. The response of the United States is also important.

One intermediate step has been proposed by Korea. Kim, Ryou and Wang (2000) have proposed an Asian Arrangements to Borrow (AAB). The AAB would operate analogously to the New Arrangements to Borrow (NAB) and General Arrangements to Borrow (GAB), ${ }^{49}$ which 
Pacific Economic Papers

provide a mechanism for the IMF to supplement its resources for lending in a financial crisis. The AAB would be a regional mechanism for creditor countries to contribute to a pool of funds that could be disbursed under specific terms and conditions to East Asian countries facing or experiencing financial crisis. They propose that the AAB be managed within the region.

The proposal needs refinement. For example, the trigger for the AAB is not well defined. Kim, Ryou and Wang (2000) say that the AAB is a device to prevent a crisis and suggest that it could be triggered when a country with sound fundamentals experiences a large currency depreciation, say 20 per cent. But this would probably be too late. It also leaves open what is meant by sound fundamentals.

\section{Common currency arrangements}

The third leg in regional financial arrangements is the adoption of some kind of common currency arrangement within East Asia or some subset of it. Common currency arrangements range from common-basket pegs (to the dollar, yen and euro), to regional currency units (a weighted sum of regional convertible currencies) to formal currency union. While there is regional consensus on the need to strengthen policy dialogue and financial cooperation, there is no consensus on common currency arrangements.

There is a wide mix of views about common currency arrangements in the region. Japan is a strong proponent of common-basket pegs. ${ }^{50}$ Korea favours the use of an Asian Currency Unit, not only for its perceived stabilising effect but because it does not concentrate decisionmaking and seignorage returns on Japan. ${ }^{51}$ ASEAN has also commissioned research on whether ASEAN should have a common currency. ${ }^{52}$

While the general view is that cooperative or common currency arrangements are still some time off, they are increasingly being thought of as a long-term policy aim. Deepening and developing regional policy dialogue and financial cooperation are important to the way in which common currency arrangements will evolve in East Asia. Strengthening financial cooperation is seen as particularly important in this respect since exchange rate cooperation must be backed by unequivocal financial cooperation if it is to work. At this stage, such commitment does not exist in the region.

The IMF will be included in the analysis of these issues but the degree to which the region seeks its advice and involvement will ultimately depend on the stance it takes. The IMF seems to have a bipolar view of what exchange rate regimes are most suitable and has less interest 
in intermediate exchange rate regimes. ${ }^{53}$ There is, in particular, little support among Fund staff for common pegged exchange rate systems because experience with such regimes is that they tend to come undone in a costly manner. While many in the region agree with this - and so regard formal currency union as the more viable common currency arrangement in the longer term - others, especially in Japan, do not.

\section{Conclusion}

The East Asian financial crisis - and particularly the way in which it was dealt with by the IMF and the United States - has been a key force behind the assertion of the new Asian regionalism and its talisman, new regional financial arrangements. This has been boosted by Europe's experience with monetary union and by increasing trade openness and integration in East Asia.

Over the past few years there has been a clear shift in policy support for strengthening regional policy dialogue, creating new forms of regional financial cooperation-including using new instruments for cooperation, developing regional financial markets, and establishing new institutions for cooperation - and thinking more seriously about common currency arrangements in East Asia, or at least part of it.

Stronger regional financial arrangements are mostly viewed in East Asia as being complementary to global financial dialogue and cooperation, embodied in the IMF. The IMF is still seen to be an important and necessary institution, not least in being there to provide assistance in large or global financial crises but also in giving countries a voice in international policymaking and securing greater interest from the United States and Europe in events beyond their own regions. But it failed the critical test in 1997 and 1998 in providing expert policy direction and in garnering international support. Regional initiatives are a way to deal with this failure.

The two crucial elements of developing regional financial arrangements at this stage are strengthening policy dialogue and deepening financial cooperation. Strengthening policy dialogue is important in its own right: it improves understanding of regional economies and markets and gives the region a stronger voice in global dialogue and policymaking. It also is a necessary condition for effective financial cooperation.

Developing new forms of regional financial cooperation and support is also important in helping protect the region from further crises. At the most elementary level, arrangements to 
deal with temporary liquidity shortfalls are not comprehensively provided at the global level but can be at a regional level.

Three arguments are most commonly made against regional support arrangements: they can weaken global arrangements, especially with respect to terms and conditions; they are too limited to deal with large regional or global crises and can cause coordination problems and inconsistency; and they need to be backed by adequate policy dialogue and surveillance processes. But none of these arguments is decisive.

First, the presumption that global arrangements are necessarily better than regional ones must be tested by actual circumstances. The IMF did poorly in the East Asian financial crisis on a number of fronts. But, having accepted this, it is time to move on and look to the future with balance. Global arrangements have particular advantages in creating some distance between borrower and lender and in providing expertise in dealing with problems in financial institutions and firms after a crisis. Regional arrangements have particular advantages in understanding economic processes in the affected countries better, ensuring that someone is interested even if the United States and Europe are not, and providing a practical way to deal with localised contagion. They may also be a substantial boost to the Fund's financial resources. By increasing the contestability of policy advice and action, they may affect the reaction of the IMF in future crises and improve international involvement and terms and conditions. Global and regional arrangements, properly structured, should be seen as complementary.

Second, large regional or global crises cannot be prevented or resolved just at the regional level and so there is a first-order argument for global arrangements, as exist with the Fund. Again the aim of regional arrangements should not be to supplant the Fund but to complement it.

Third, strong effective policy dialogue, including surveillance, is necessary for wellfunctioning arrangements for financial support. The region is not there yet, but policymakers understand this and are working to improve dialogue. This will take time, as will the establishment of working financial support arrangements.

Progress on strengthening regional financial arrangements has been modest. Policy dialogue has been expanded through the Manila Framework Group and ASEAN+3 Finance Ministers meetings, although both forums have different strengths and weaknesses. Financial cooperation has been increased through the ASEAN+3 framework, with the expansion of the ASEAN currency swaps and introduction of a comprehensive network of bilateral swaps 
between ASEAN+3 countries, which aggregate to about US\$30 billion. While important symbolically as a first step in ASEAN+3 cooperation, the amounts involved are too small to use in a financial crisis.

There is still a long way to go in developing regional policy dialogue and financial cooperation, let alone common currency arrangements, in East Asia. The path of financial and economic integration in East Asia is not predetermined. The ultimate form and substance of regional financial arrangements is highly contingent on future circumstances and the willingness of countries in the region to engage and cooperate with each other. The process is iterative and messy. But it is underway, and the policy and political dynamic behind it is irreversible.

As regional financial arrangements progress, a major challenge for the region will be to articulate and then actualise the sort of relationship it wants with the IMF. While resentment and disillusion with the Fund still run deep - although less intensely than in 1997 and 1998 - the region needs to think pragmatically and strategically about the issue. The IMF is an essential part of the global financial architecture. Regional mechanisms and institutions can be an important complement to global ones but it is unrealistic to expect them to fully replace global ones. Developing regional policymaking at the expense of better global policymaking may be ultimately self-defeating: the more the region disengages from global processes and the IMF, then the less likely the IMF will be suitably responsive to the conditions and needs of the region in future crises. A regional financial architecture is most unlikely to have the financial and technical capacity to deal with every financial crisis that affects East Asia. To be most effective, the development of a new regional financial architecture has to go hand-in-hand with renewed commitment to, and the exercise of leadership in, the Fund by the region.

\section{Notes}

* Professor of Economics, Asia-Pacific School of Economics and Management, Australian National University, Canberra, ACT 0200, Australia; gordon.debrouwer@anu. edu.au. I am grateful to Peter Drysdale, Jeff Frankel, Prasanna Gai, Chris Gilbert, Randy Henning, David Vines and many (anonymous) officials from the region for their comments and feedback. The views and opinions expressed here, and any errors and inaccuracies made, are my own. Comments and corrections are welcome. This paper is being published in Chris Gilbert and David Vines (eds), The IMF and the International Financial Architecture Cambridge University Press, forthcoming 2003.

1 The East Asian region includes China, Hong Kong SAR, Japan, Korea and Taiwan, the 10 ASEAN countries (Brunei, Burma, Cambodia, Indonesia, Laos, Malaysia, the 
Philippines, Singapore, Thailand and Vietnam), and Australia and New Zealand. The latter two countries are included because they are deeply economically integrated with the region, in both trade and in finance, and have a long history of policy interaction with many countries in the region: this was acknowledged by Japanese Prime Minister Koizumi's inclusion of them in his January 2002 Singapore speech outlining his vision of an East Asian community.

$2 \quad$ It is an oversimplification to say that a region as large and diverse as East Asia has any particular view, but that does not mean it is not possible or incorrect to attempt to describe broad sentiment at times.

For references and the IMF staff's explanation and defence, see Boorman et al. (2000).

See chapter 3 in de Brouwer (2001). As shown by its Capital Market Reports in 1999 and 2000, the Fund, or parts of it, may have subsequently become less sceptical.

It is hard to source public quotes by officials along these lines, but this was certainly the private sentiment of many officials in the region.

Funds of US $\$ 17.1$ billion, US $\$ 36.2$ billion and US $\$ 58.9$ billion were committed to Thailand, Indonesia and Korea, respectively, in 1997 and 1998. The IMF components were US $\$ 3.9$ billion, US $\$ 11.2$ billion and US $\$ 20.9$ billion, respectively. The World Bank was also involved in these programs but its involvement seems to many to be beyond the scope of its charter. The size of the financing requirements also raises the need for private sector involvement in the prevention and resolution of financial crises.

See Costello (1999).

This is based on the author's discussions with policymakers in the region. See also Macfarlane (1997a, b) and Grenville (1997, 1998).

9 An oft-quoted example is the closure of 16 banks in Indonesia in November 1997. It led to widespread panic because depositors feared that this was just the start of a wave of closures.

10 See, for example, Yoshitomi and Ohno (1999).

11 See, for example, Ito, Sasaki and Ogawa (1998); Williamson (2001); Kawai and Akiyama (2000); Kawai and Takagi (2000); and Yoshino, Koji and Suzuki (2000).

12 See Ogawa (2000) and Kawai (2001). De Brouwer (2002a) looks at alternative explanations.

13 See, for example, Lee and Yang (2001).

14 See, for example, Yamamoto, Thiparat and Ahsan (2001).

15 This is how a pro-US senior Thai journalist described local sentiment to the author.

16 This is the assessment of a variety of senior officials across the region based on their discussions with some senior members of the US Administration in 1998.

17 See Financial Stability Forum Working Group on Highly Leveraged Institutions (2000).

18 See de Brouwer (2001).

19 See Rice (2000). 
20 Loosely analogous to the aim of balance enshrined in the separation of powers in the US constitution. This is an argument that was used, for example, by Federal Reserve Chairman Alan Greenspan in 1999 against the consolidation of prudential supervision in the United States into one institution.

21 Based on GDP, Europe is over-represented by about 6 per cent in IMF quotas, while Japan and the United States are under-represented by 12 per cent and 9 per cent, respectively. The Dutch, Saudi Arabian and Belgian constituencies are the most overrepresented in terms of IMF quotas.

22 A swap involves exchanging domestic currency for a fixed amount of foreign currency, typically US dollars, for a fixed period at a predetermined price.

23 At the same time, they are wary of being swallowed up by the big three.

24 See Kim, Ryou and Wang (2000) and Kim and Yang (2001). The EMS and East Asian crises were, however, different types of crisis requiring different policy responses: the former was a monetary crisis, the latter a financial crisis.

25 See, for example, Kim, Ryou and Wang (2000). They summarise the views of 'western scholars' and say that, 'Nevertheless, regional financial arrangements could be structured and executed so as to be complementary to the role of the IMF'.

26 See Yamamoto, Thiparat and Ahsan (2001). This is not just felt with respect to the Americans. Some in the region also find the Asia-Europe Meeting (ASEM) discussions a little one-sided at times, with the perception being that the Europeans are there to teach and the Asians are there to learn, rather than having a focus on genuine dialogue and exchange.

27 See Henning (2002).

28 See the statement, A New Framework for Enhanced Asian Regional Cooperation to Promote Financial Stability, at <www.mof.go.jp/english/if/if000a.htm>.

29 See the Chairman's Summary of the 8th Finance and Central Bank Deputies Meeting of the Manila Framework Group, 8-9 March 2001, Beijing, available at<www.mof.go.jp/ english/if/if037.htm> and the Press Release of the 9th Meeting of the Manila Framework Group on 4-5 December 2001.

30 This and some other ASEAN+3 statements are available at <www.mofa.go.jp/region/ asia-paci-asean $>$ and at the ASEAN Web site, $<$ www.aseansec.org $>$.

31 The way in which groups of countries develop policy dialogue depends in part on the issues that they meet to discuss and in part on the history of their interaction. What works in one case may not work in another. East Asia is different from Europe: economic development is a key priority in a region as diverse as East Asia; openness and market-orientation are essential to a region like East Asia that depends on broadbased world economic growth; and the history of interaction in East Asia is different from that of interaction in Europe.

See Wyplosz (2001), Rollo (2001) and Pisani-Ferry (2001).

33 See Kim, Ryou and Wang (2000); SaKong and Wang (2000); and de Brouwer (2001). Following recent interventions by Anne Krueger, the First Deputy Managing Director 
of the IMF, the prospects for setting up mechanisms for private-sector involvement in financial crises now seem brighter.

34 The distinction between funding a short-term liquidity shortfall and preventing a financial crisis may be an artificial one: it is hard to see how in practice a country can have a short-term liquidity problem in international payments without generating a financial crisis.

35 See Obstfeld (1996); and Corsetti, Dasgupta, Morris and Shin (2000).

36 See Dornbusch, Park and Clasessens (2000). This does not imply that the events of 1997 and 1998 were only due to contagion; see de Brouwer $(1999,2001)$. There is also considerable debate between economists about the existence and prevalence of contagion; see, for example, Edwards and Susmel (2000); Bordo and Murshid (2000); and Rigobon (2001).

37 IMF lending for a liquidity squeeze depends on the nature and size of the shock. The Compensatory Financing Facility (CFF), for example, is available to countries which experience a sudden shortfall in export earnings or increase in the cost of food imports caused by fluctuating world commodity prices. See the IMF Web site, for example at $<$ www.imf.org/external/np/exr/facts/howlend.htm>, for a summary of the IMF lending facilities.

38 This is the standard assumption, but it is just an assertion. See Henning (2002) for an interesting discussion.

39 The Asian Development Bank, for example, has many excellent and capable professionals, but it is generally regarded as less prestigious than the World Bank and unable to attract the same quality of staff.

40 The weakness of the Executive Board in monitoring staff and management and leading the Fund's policymaking is a serious and complex issue. On the one hand, governance is weak because management and staff bypass the Board. For example, management use 'side letters' in packages that the Board does not review, although these are now used less than before the crisis. Management also at times pre-empts the Board in critical matters, as occurred with the Russian emergency package in 1998. There is widespread dissatisfaction at the Board with the narrow policy options and limited information presented to it by staff. But, on the other hand, the Executive Board does not exercise its duties as well as it could. Some Board members are appointed for convenience, seniority or prestige rather than on merit. Some members of the Board have leaked sensitive material for political gain, which led to the use of side letters in the first place. And, from the management point of view, there is little appetite at the Board for taking responsibility and making decisions. The effectiveness of the Board ultimately depends on the commitment of national governments to the Fund.

41 See Stanley Fischer's (2001) exhortation to Asian policymakers to improve the quality of their representatives on the Executive Board and engage more with IMF staff and management at the Executive Board.

42 Some would argue that a regional fund would have made the crisis worse by weakening the commitment to reform and by raising the stakes in the game. On the latter point, the macro hedge funds faced no external financing constraints from the investment 
banks and securities firms that funded their short speculative currency positions in 1997 and 1998, and could have increased their positions as the level of reserves increased (Financial Stability Forum Working Group on Highly Leveraged Institutions 2000; de Brouwer 2001). Whether this would have happened is unknowable, and would probably have depended on the credibility of the regional fund and package.

See Parkinson, Garton and Dickson (2002) for a discussion on first- and second-tier financing.

44 Australia and Hong Kong also opposed the AMF proposal at the time.

45 See Kim, Ryou and Wang (2000: 29-30) for details.

46 Including IMF conditionality was controversial but was agreed to because it was thought important to link regional arrangements with global arrangements and ensure that appropriate conditionality is applied. This helps establish the credibility of the system and assuage concerns that regional arrangements are designed to subvert global arrangements.

47 See Financial Stability Forum Working Group on Highly Leveraged Institutions (2000) and de Brouwer (2001).

48 The main macro hedge funds involved in these positions had essentially limitless access to fund their positions (Financial Stability Forum Working Group on Highly Leveraged Institutions 2000). Their positions would most likely have been larger had reserves positions and the commitment to maintain exchange rates at prevailing levels been greater.

49 See Kim, Ryou and Wang (2000) and < www.imf.org/external/np/exr/facts/gabnab.htm>.

50 See Goto and Hamada (1994); Ito, Ogawa and Sasaki (1998); Council on Foreign Exchange and Other Transactions (1999); Murase (2000); Ogawa and Ito (2000); Ogawa (2000); Kawai and Akiyama (2000); Kawai and Takagi (2000); Yoshino, Koji and Suzuki (2000). Dornbusch and Park (1999), Williamson $(1999,2001)$ and Kwan (2001) are also supportive. See de Brouwer (2002b) for an alternative view.

51 See Kim, Ryou and Wang (2000); Moon, Rhee and Yoon (2000); Ryou and Kim (2001); and Moon and Rhee (2002).

52 See Bayoumi and Mauro (1999).

$53 \quad$ See Mussa et al. (2000) and Fischer (2001).

\section{References}

Bayoumi, T. and P. Mauro (1999) 'The Suitability of ASEAN for a Regional Currency Arrangement', I MF Working Paper WP/99/102, Washington DC, International Monetary Fund.

Boorman, J., T. Lane, M. Schulze-Ghattas, A. Bulir, A. Ghosh, J. Hamann, A. Mourmouras, and S. Phillips (2000) 'Managing Financial Crises: The Experience in East Asia', I MF Working Paper WP/00/107, Washington DC, IMF June. 
Bordo, M.D. and A.P. Murshid (2000) 'Are Financial Crises Becoming Increasingly More Contagious? What is the Historical Evidence on Contagion?', NBER Working Paper No. 7900, September.

Corsetti, G., A. Dasgupta, S. Morris and H.S. Shin (2000) 'Does One Large Soros Make a Difference? A Theory of Currency Crises with Large and Small Traders', mimeo.

Costello, P. (1999) Australia and the IMF, Annual Report to the Parliament under the International Monetary Arrangements Act 1947, Australian Government Printing Service, Canberra.

Council on Foreign Exchange and Other Transactions, (1999) 'Internationalisation of the Yen for the 21st Century', see <www.mof.go.jp/english/if/elb064a.htm>.

de Brouwer, G.J. (1999) Financial Integration in East Asia, Cambridge, Cambridge University Press.

-- (2001) Hedge Funds in Emerging Markets, Cambridge, Cambridge University Press.

- (2002a) 'Debating Financial Markets and Policies in East Asia', chapter 1 in Gordon de Brouwer (ed.) Financial Markets and Policies in East Asia, London, Routledge, 1-16.

de Brouwer, G.J. (2002b) 'Does a Formal Common-Basket Peg in East Asia Make Economic Sense?', chapter 12 in Gordon de Brouwer (ed.) Financial Markets and Policiesin East Asia, London, Routledge, 286-314.

Dornbusch, R. and Y.C. Park (1999) 'Flexibility or Nominal Anchors?' chapter 1 in S. Collignon, J. Pisani-Ferry and Y.C. Park (eds) Exchange Rate Policies in Emerging Asian Countries, London, Routledge, 3-34.

Dornbusch, R., Y.C. Park, and S. Claessens (2000) 'Contagion: Understanding How It Spreads', World Bank Research Observer, 15(2), 177-97.

Edwards, S. and R. Susmel (2000) 'Interest Rate Volatility and Contagion in Emerging Markets: Evidence from the 1990s', NBER Working Paper No. 7813, July.

Eichengreen, B. and T. Bayoumi (1999) 'Is Asia An Optimum Currency Area? Can It Become One? Regional, Global, and Historical Perspectives on Asian Monetary Relations', chapter 21 in S. Collignon, J. Pisani-Ferry and Y.C. Park (eds) ExchangeRatePolicies in Emerging Asian Countries, London, Routledge, 347-66.

Financial Stability Forum Working Group on Highly Leveraged Institutions (2000) Report, see $<$ www.fsforum.org $>$.

Fischer, S. (2001) 'Asia and the IMF', remarks made at the Institute of Policy Studies, Singapore, 1 June. See <www.imf.org/external/np/speeches/2001/060101.htm>.

Goto, J. and K. Hamada (1994) 'Economic Preconditions for Asian Regional Integration', in T. Ito and A. Kruger (eds) Macroeconomic Linkage: Savings, Exchange Rates, and Capital Flows, Chicago, University of Chicago Press, 359-88.

Grenville, S.A. (1997) 'Asia and the Financial Sector, Reserve Bank of Australia Bulletin, December.

Grenville, S.A. (1998) 'The Asian Economic Crisis', ReserveBank of Australia Bulletin, April.

Henning, C.R. (2002) 'East Asian Financial Cooperation After Chiang Mai', Institute for International Economics, Washington DC, mimeo.

Ito, T., E. Ogawa and Y.N. Sasaki (1998) 'How Did the Dollar Peg Fail in Asia?', NBER Working Paper No. 6729, Cambridge Mass., National Bureau of Economic Research. 
Katzenstein, P.J. (1996) 'Regionalism in Comparative Perspective', Cooperation and Conflict 31, 123-60.

Kawai, M. and S. Akiyama (2000) 'Implications of the Currency Crisis for Exchange Rate Arrangements in Emerging East Asia', mimeo, Washington DC, World Bank.

Kawai, M. and S. Takagi (2000) 'The Strategy for a Regional Exchange Rate Arrangement in Post-Crisis East Asia: Analysis, Review and Proposal', mimeo, Washington DC, World Bank.

Kawai, M. (2001) 'Recommending a Currency Basket System for Emerging East Asia', paper presented at a conference on Regional Financial Arrangements in East Asia, organised by the Australia-Japan Research Centre, The Australian National University, 12-13 November.

Kim, T.J., J.W. Ryou and Y. Wang (2000) Regional Arrangements to Borrow: A Scheme for Preventing Future Asian Liquidity Crises, Seoul, Korea Institute for International Economic Policy.

Kim, T.J. and D.Y. Yang (eds) (2001) N ew International Financial Architecture and Korean Perspectives, Seoul, Korea Institute for International Economic Policy.

Kwan, C.H. (2001) Yen Bloc: Toward Economic Integration in Asia, Washington DC, Brookings Institution Press.

Lee, H.H. and D.Y. Yang (2001) 'Reforming the International Financial Architecture', chapter 1 in T.-J. Kim and D.Y. Yang (eds) New International Financial Architecture and Korean Perspectives, Seoul, Korea Institute for International Economic Policy, 933 .

Macfarlane, I.J. (1997a) 'Statement to Parliamentary Committee', ReserveBank of Australia Bulletin, November.

Macfarlane, I.J. (1997b) 'The Changing Nature of Economic Crises, ReserveBank of Australia Bulletin, December.

Moon, W.S., Y.S. Rhee and D.R. Yoon (2000) 'Asian Monetary Cooperation: A Search for Regional Monetary Stability in the Post-Euro and Post-Asian Crisis Era', Bank of Korea E conomic Papers, 3(1), 157-93.

Moon, W.S. and Y.S. Rhee (2002) 'Foreign Exchange Market Liberalisation in Korea: Past and Future Options', in K.T. Lee (ed.) Globalization in the New Millennium, London, Routledge.

Murase, T. (2000) Ajia Antei Tsuukaken: Yurooni Manabu Yen noYakuwari (The Asian Zone of Monetary Stability: Lessons from the Euro and Role of the Yen), Tokyo, Keiso Shobo.

Mussa, M., P. Masson, A. Swoboda, E. Jadresic, P. Mauro and A. Berg (2000) ExchangeRate Regimes in an Increasingly Integrated World, Washington DC, International Monetary Fund, April.

Obstfeld, M. (1996) 'Models of Currency Crises With Self-Fulfilling Features', European E conomic Review 40(3-5), 1037-47.

Ogawa, E. (2000) 'East Asian Countries Return to the Dollar Peg Again?', mimeo, Tokyo, Hitotsubashi University.

Ogawa, E. and T. Ito (2000) 'On the Desirability of a Regional Basket Currency Arrangement', mimeo, March. 
Parkinson, M., P. Garton and I. Dickson (2002) 'Regional Financial Arrangements: What Role in the International Financial Architecture?', paper presented at the CCER Peking University/AJRC ANU Conference on Deepening Financial Arrangements in East Asia, Beijing, 24-25 March.

Pisani-Ferry, J. (2001) 'The European Experience with Regional Financial Arrangements', paper presented at a conference on Regional Financial Arrangements in East Asia, organised by the Australia-Japan Research Centre, The Australian National University, 12-13 November.

Rice, C. (2000) 'Campaign 2000: Promoting the National Interest', Foreign Affairs, January/ February.

Rigobon, R. (2001) 'Contagion: How to Measure It?', NBER Working Paper No. 8118, February.

Rollo, J. (2001) 'Monetary Cooperation and Policy Dialogue: The European Experience', paper presented at a conference on Regional Financial Arrangements in East Asia, organised by the Australia-Japan Research Centre, The Australian National University, 12-13 November.

Ryou, J.W. and T.J. Kim (2001) 'The Choice of Exchange Rate Regime and Capital Mobility: An Emerging Market Economies Perspective', chapter 4 in T.J. Kim and D.Y. Yang (eds) (2001) New I nternational Financial Architectureand Korean Perspectives, Seoul, Korea Institute for International Economic Policy, 87-108.

SaKong, I. and Y. Wang (2000) R eforming thel nternational Financial Architecture: Emerging Market Perspectives, Seoul Institute for Global Economics and Korea Institute for International Economic Policy.

Williamson, J. (1999) The Case for a Common Basket Peg for East Asian Currencies', chapter 19 in S. Collignon, J. Pisani-Ferry and Y.C. Park (eds) Exchange Rate Policies in Emerging Asian Countries, London, Routledge, 327-43.

Williamson, J. (2001) 'The Case for a Basket, Band and Crawl (BBC) Regime in East Asia', in D. Gruen and J. Simon (eds) Future Directions for Monetary Policies in East Asia, Sydney, Reserve Bank of Australia, 97-112. See <www.rba.gov.au/ PublicationsAndResearch/Conferences/2001>.

Wyplosz, C. (2001) 'A Monetary Union in East Asia? Some Lessons from Europe', in D. Gruen and J. Simon (eds) Future Directions for Monetary Policies in East Asia, Sydney, Reserve Bank of Australia, 124-55. See <www.rba.gov.au/PublicationsAndResearch/ Conferences/2001>.

Yamamoto, T., P. Thiparat, and A. Ahsan (2001) America's Role in Asia: Asian Views, San Francisco, The Asia Foundation.

Yoshino, N., S. Koji and A. Suzuki (2000) 'Basket Peg, Dollar Peg, and Floating: A Comparative Analysis of Exchange Rate Regimes', mimeo, Tokyo, Keio University.

Yoshitomi, M. and K. Ohno (1999) 'Capital Account Crisis and Credit Contraction: A New Nature of Crises Requires New Policy Papers', Asian Development Bank Institute Working Paper 2. 


\section{Previous Pacific Economic Papers}

323 APEC and the new economy

Mari Pangestu and Sung-hoon Park, January 2002

322 East Asian steel projections for the 1990s revisited

Ben Garvey and Peter Drysdale, December 2001

321 Evidence of shifts in the determinants of the structure of Japanese manaufacturing trade, $1970-95$

Peter Drysdale and Ligang Song, November 2001

320 The services content of Japanese trade

Kozo Kiyota, October 2001

319 Changes in the Japanese food sector

Ray Trewin et al., September 2001

318 The changing economic performance and political significance of Japan's agricultural cooperatives

Yoshihisa Godo, August 2001

317 Bank and corporate restructuring in crisis-affected East Asia: from systemic collapse to reconstruction

Masahiro Kawai, July 2001

316 Hot and spicy: ups and downs on the price floor and ceiling at Japanese supermarkets

Kenn Ariga, June 2001

315 China's admittance to the WTO and industrial structural adjustment in the world economy

Christopher Findlay, May 2001

314 'Japan Inc.' in the agricultural sector: reform or regression?

Aurelia George Mulgan, April 2001

313 Encouraging 'democracy' in a Cold War climate: the dual-platform policy approach of Evatt and Labor toward the allied occupation

Christine de Matos, March 2001

312 Managing capital flows: a distortions approach

Dominic Wilson, February 2001

311 Old issues in new regionalism

Christopher Findlay, January 2001 
310 Trade conflicts between Japan and the United States over market access: the case of automobiles and automotive parts

Masao Satake, December 2000

309 Subregional trading arrangements among APEC economies: managing diversity in the Asia Pacific

Andrew Elek, November 2000

308 Weathering the Asian crisis: the role of China

Yongzheng Yang and Rod Tyers, October 2000

307 The internationalisation of the yen: essential issues overlooked

Tetsuji Murase, September 2000

306 Japan's local governance at the crossroads: the third wave of reform

Purnendra Jain, August 2000

305 Some key issues for the East Asian food sector

$M$. Honma, R. Trewin, M. Bosworth, R. Stringer and Y. Godo, July 2000

(special volume)

304 Food embargoes against China: their likelihood and potential consequences

Yongzheng Yang, June 2000

303 Foreign direct investment and intra-industry trade - the case of the United States Tina Yiping Chen, May 2000

302 Implications of recent Japanese legal reforms

Leon Wolff, Veronica Taylor and Akiyoshi Horiuchi, April 2000

(special volume)

301 Toward reform and transparency in Japanese policymaking processes

J.A.A. Stockwin, Jennifer Amyx and Gregory Noble, March 2000

(special volume)

300 A way forward for Japanese agriculture?

Masayoshi Homna, Ray Trewin, Jennifer Amyx and Allan Rae, February 2000

(special volume)

299 Japanese foreign direct investment in the world economy 1951-1997

Roger Farrell, January 2000

298 The genesis of APEC: Australian-Japanese political initiatives

Takashi Terada, December 1999

297 Is shutting Krugman's 'liquidity trap' the answer to Japan's problems?

Dominic Wilson, November 1999 
296 Japanese government-business collaboration and the operations of Japanese corporations in Asia: A telecommunications case

Hidetaka Yoshimatsu, October 1999

295 Free trade champion? Australian views of the US crusade against Japan Julia Lowell, September 1999

294 Governance and Australian financial institutions Kevin Davis, August 1999

293 The changing climate for foreign direct investment into Japan

Peter Drysdale, Ray Trewin, Toshi Naito and Dominic Wilson, July 1999

292 The Japanese origins of PAFTAD: The beginning of an Asian Pacific economic community

Takashi Terada, June 1999

291 Not just a question of multilateral free trade: Australia's bilateral trade liberalisation agenda towards Japan J amie Anderson, May 1999

290 Perspectives on Japanese investment, employment and management in Australia Roger Farrell and Peter Drysdale, April 1999

289 Predicting banking crises: Japan's financial crisis in international comparison Michael Hutchinson and Kathleen McDill, March 1999

288 Japan's financial reform Volume I

Hugh Patrick and Takatoshi I to, February 1999

287 International trade and environmental policy: how effective is 'eco-dumping? Xinpeng Xu, January 1999

286 Open regionalism going global: APEC and the new transatlantic economic partnership Andrew Elek, December 1998

285 Realism and postwar US trade policy J ohn Kunke, November 1998

284 Attracting FDI: Australian government investment promotion in Japan, 1983-96 J amie Anderson, October 1998

283 The Multi-function polis 1987-97: an international failure or innovative local project?

Paul Parker, September 1998 
282 Organisation, motivations and case studies of Japanese direct investment in real estate 1985-94

Roger Farrell, August 1998

281 Japan's approach to Asia Pacific economic cooperation

Peter Drysdale, July 1998

280 The politics of telecommunications reform in Japan

Hidetaka Yoshimatsu, June 1998

279 Sustainability of growth in the Korean manufacturing sector

Chang-Soo Lee, May 1998

278 Export performance of environmentally sensitive goods: a global perspective Xinpeng Xu, April 1998

277 Modelling manufactured exports: evidence for Asian newly industrialising economies

Francis In, Pasquale Sgro and J ai-Hyung Yoon, March 1998

Annual subscription rate for twelve issues:

Individuals A $\$ 60.00$

Institutions A $\$ 100.00$

\section{Cost for single issues:}

$\mathrm{A} \$ 15.00$

$\mathrm{A} \$ 10.00$ (Students)

All prices include postage

Available from: Publications Department

Australia-Japan Research Centre

Asia Pacific School of Economics and Management

The Australian National University

Canberra ACT 0200, Australia

Facsimile: (61 2) 62490767

Telephone: (61 2) 62493780

E-mail:ajrc@anu.edu.au

URL: http://ajrcnet.anu.edu.au/ 